ROCZNIKI NAUK PRAWNYCH

Tom XXXI, numer $1-2021$

DOI: https://doi.org/10.18290/rnp21311-10

PAWEŁ KALETA

\title{
UPRAWNIENIE KONFERENCJI BISKUPÓW DO USTANOWIENIA AKTÓW NADZWYCZAJNEGO ZARZĄDZANIA
}

\begin{abstract}
WSTĘP
Zarządzanie dobrami kościelnymi stanowiło już przedmiot badań w polskiej literaturze kanonistycznej. Analizowane głównie były akty zarządzania zwyczajnego i nadzwyczajnego ${ }^{1}$. Niemniej uprawnienia konferencji biskupów do określenia aktów nadzwyczajnego zarządzania nie były przedmiotem gruntownej analizy w polskiej kanonistyce. Należy jednakże podkreślić, że Konferencja Episkopatu Polski w Instrukcji w sprawie zarzadzania dobrami doczesnymi Kościoła ${ }^{2}$ stwierdziła, że „wykaz aktów (czynności) nadzwyczajnego zarządzania zostanie ustalony w odrębnym akcie prawnym". Niemniej żaden dekret w tej sprawie nie został, jak dotąd, wydany przez Konferencję Episkopatu Polski. Ich określenie wydaje się o tyle istotne, że brak ich powoduje trudność w uznaniu, czy dana czynność administracyjna jest aktem nadzwyczajnego zarządzania (kan. 1277), czy transakcją, która może pogorszyć stan majątkowy kościelnej osoby prawnej (kan. 1295).
\end{abstract}

Ks. dr hab. PaweŁ Kaleta, prof. KUL - Katedra Kościelnego Prawa Publicznego i Konstytucyjnego, Instytut Prawa Kanonicznego, Wydział Prawa, Prawa Kanonicznego i Administracji Katolickiego Uniwersytetu Lubelskiego Jana Pawła II, ul. Spokojna 1, 20-950 Lublin; e-mail: kaleta.kul@gmail.com; ORCID: https://orcid.org/0000-0001-6159-0997.

${ }^{1}$ S. Dubiel, Akty nadzwyczajnego zarzadzania w Kodeksie Prawa Kanonicznego z 1983 r., „Roczniki Nauk Prawnych” 25 (2015), nr 4, s. 113-131; L. ŚwiTo, Akty zarządu dobrami kościelnymi, „Prawo Kanoniczne” 58 (2015), nr 3, s. 105-116. P. KALETA, Prawne aspekty zarzadzania dobrami kościelnymi, Lublin: Wydawnictwo KUL 2017.

${ }^{2}$ KonferencJa EPISKOPATU POLSKI, Instrukcja Konferencji Episkopatu Polski w sprawie zarządzania dobrami doczesnymi Kościoła (25.08.2015), „Akta Konferencji Episkopatu Polski” 27 (2015), s. 116-140 [dalej: IKEP]. 
Analizując akty nadzwyczajnego zarządzania pojawić się może pytanie, czy brak określenia aktów nadzwyczajnego zarządzania przez konferencję biskupów oznacza, że biskup diecezjalny nie realizuje ich w diecezji? Czy $\mathrm{w}$ takiej sytuacji biskup powinien zastosować procedurę przewidzianą dla aktów o większym znaczeniu (kan. 1277 in principio), czy transakcji, która może pogorszyć stan majątkowy kościelnej osoby prawnej? Zanim podejmie się próbę odpowiedzi na te pytania, najpierw zostanie ukazana geneza aktów nadzwyczajnego zarządzania, następnie zdefiniowane pojęcie „zarządzania”, by ostatecznie przedstawić analizę prawno-dogmatyczną stwierdzenia Conferentiae autem Episcoporum est definire quinam actus habendi sint extraordinariae administrationis zawartego w kan. 1277.

\section{GENEZA AKTÓW NADZWYCZAJNEGO ZARZĄDZANIA}

Zgodnie z kan. 1254 § 1 Kościół na podstawie ius nativum ma prawo, niezależnie od władzy świeckiej, zarządzać własnym majątkiem. Prawo to odnosi się również do formułowania własnej teorii o zarządzaniu dobrami kościelnymi. W dokumentacji kościelnej wyrażenie actus extraordinariae administrationis po raz pierwszy zostało zastosowane w dekrecie Świętej Kongregacji Rozkrzewiania Wiary z dnia 21 lipca 1856 r. $^{3}$ Adresatem tegoż dokumentu była Archidiecezja Utrechtu w Holandii, dla którego Kongregacja określiła katalog czynności, które stanowią akty nadzwyczajnego zarządzania. Do nich należały m.in.:

1) przyjęcie lub zrzeczenie się spadków, zapisów, darowizn (zawartych uroczyście) lub fundacji;

2) kupno nieruchomości;

3) sprzedaż, wymiana, kredyt hipoteczny, oddanie w zastaw, obciążenie innego rodzaju służebnościami lub wynajem powyżej trzech lat nieruchomości kościelnych;

4) sprzedaż, wymiana, zastaw lub jakiekolwiek inne użycie niezgodne z przeznaczeniem dzieł sztuki, zbiorów dokumentów lub innego mienia o dużym znaczeniu;

\footnotetext{
${ }^{3}$ Sacra Congregatio de Propaganda Fide, Statuta generalia deconciliis quae bonis temporalibus ecclesiarum administrandis in archidioecesi Ultraiectensi et suffraganieis diocesibus proponuntur (21.07.1856), [w:] Codicis Iuris Canonici Fontes, red. P. Gasparri, J. Serédi, vol. VII, Typis Polyglottis Vaticanis 1926-1939, nr 4841, s. 347-348.
} 
5) zaciąganie pożyczek na duże sumy pieniędzy, zawieranie transakcji i innych umów z dużymi obciążeniami [finansowymi];

6) wzniesienie, zburzenie lub przebudowa i nadzwyczajne naprawy budynków kościelnych;

7) założenie cmentarza;

8) erygowanie lub zniesienie parafii, lub rzeczy należących do kościoła parafialnego, lub instytutu;

9) nałożenie daniny, wprowadzenie zbiórek, lub przeznaczenie na inne cele tych, które Kościół [już] posiada;

10) udział w procesie czy to jako powód, czy to jako oskarżony.

Analiza tychże aktów w obecnym stanie prawnym budzi wiele zastrzeżeń, ponieważ do aktów nadzwyczajnego zarządzania zostały dodane również te, które w obowiązującym Kodeksie Prawa Kanonicznego z 1983 r. ${ }^{4}$ są aktami alienacji, np. sprzedaż, wymiana czy zastaw ${ }^{5}$. Ustawodawca dziś wyraźnie odróżnia akty zarządzania od aktów alienacji (kan. 1254). Co więcej, wobec aktów alienacji zostały przewidziane odrębne przepisy procedury administracyjnej (kan. 1291-1294), nie wyłączając w tym zezwolenia Stolicy Świętej, gdy jej wartość przekracza maksymalną kwotę alienacji, lub gdy chodzi o rzeczy kosztowne z racji artystycznych lub historycznych (kan. 1292 § 2).

\section{ROZWÓJ DOKTRYNY DOTYCZĄCEJ AKTÓW NADZWYCZAJNEGO ZARZĄDZANIA}

Analiza teorii prawa kanonicznego dotycząca aktów nadzwyczajnego zarządzania dowodzi, że pojęcie to ma relatywnie krótką historię powstania. Wyrażenie actus extraordinariae administrationis niestety nie pojawiło się w Kodeksie Prawa Kanonicznego z 1917 r. ${ }^{6}$ W kan. $1520 \S 3$ KPK/17 była jedynie wzmianka o aktach większego znaczenia (łac. actibus maioris momenti), który w obecnym stanie prawnym nie jest odpowiednikiem przepisów prawnych dotyczących aktów nadzwyczajnego zarządzania. W celu ich dokonania

\footnotetext{
${ }^{4}$ Codex Iuris Canonici auctoritate Ioannis Pauli PP. II promulgatus (25.01.1983), „Acta Apostolicae Sedis" [dalej: AAS] 75 (1983), part II, s. 1-317; Kodeks Prawa Kanonicznego, przekład polski zatwierdzony przez Konferencję Episkopatu, Poznań: Pallottinum 1984 [dalej: KPK/83].

${ }^{5}$ Zob. D.J. WALKOWIAK, Ordinary and Extraordinary Administration, [w:] Church Finance Handbook, red. K.E. McKenna, L.A. DiNardo, J.W. Pokusa, Washington: Canon Law Society of America 1999, s. 187.

${ }^{6}$ Codex Iuris Canonici auctoritate Pii X Pontificis Maximi iussu digestus. Benedicti Papae XV auctoritate promulgatus (27.05.1917), AAS 9 (1917), part II, s. 2-523 [dalej: KPK/17].
} 
ordynariusz miejsca zobowiązany był uzyskać opinię od rady administracyjnej ${ }^{7}$.

Istotnym czynnikiem dla rozwoju nauki prawa kanonicznego w zakresie zarządzania dobrami stały się dekrety Soboru Watykańskiego II, do których należały m.in.: dekret o posłudze i życiu prezbiterów Presbyterorum ordinis $(17,20,21)^{8}$; dekret o przystosowanej do współczesności odnowie życia zakonnego Perfectae caritatis (13) ${ }^{9}$; dekret o apostolstwie świeckich Apostolicam actuositatem (10) ${ }^{10}$ oraz dekret o misyjnej działalności Kościoła $A d$ gentes $(41)^{11}$. Dekrety te nie dotyczyły stricte dóbr doczesnych Kościoła, lecz traktowały je drugorzędnie, mając na celu wyjaśnienie przedmiotowej treści dokumentu.

Kolejnym etapem na drodze formowania się teorii o aktach nadzwyczajnego zarządzania stały się prace Coetus de bonis Ecclesiae temporalibus, która miała dokonać rewizji przepisów zawartych w KPK/17 i przygotować schemat kanonów nowego kodeksu. Mimo że zespół ten został powołany już w 1968 r., to jednak postulat dotyczący aktów nadzwyczajnego zarządzania pojawił się dopiero po 13 latach, a dokładnie w 1981 r. Zainicjował ją Joseph Bernardin (USA) podczas prac Papieskiej Komisji ds. Rewizji Kodeksu Prawa Kanonicznego w 1981 r., która wydała własne Relatio na podstawie wcześniej przygotowanych schematów kanonów opracowanych przez Coetus de bonis Ecclesiae temporalibus ${ }^{12}$. Arcybiskup Bernardin stwierdził, że konferencja danego kraju zobowiązana jest określić, które czynności należy uznać za akty nadzwyczajnego zarządzania lub określić ogólne kryteria aktów nadzwyczajnego zarządzania. W odpowiedzi Sekretariat Papieskiej Komisji ds. Rewizji Kodeksu

\footnotetext{
${ }^{7}$ S. DuBIEL, Akty nadzwyczajnego zarządzania, s. 116.

${ }^{8}$ Concilium Oecumenicum Vaticanum II, Decretum de presbyterorum ministerio et vita Presbyterorum ordinis (07.12.1965), AAS 58 (1966), pp. 991-1024; tekst polski: Sobór Watykański II, Konstytucje. Dekrety. Deklaracje, Poznań: Pallottinum 2002, s. 478-508.

${ }^{9}$ Concilium OeCUMENICUM VATICANUM II, Decretum de accommodata renovatione vitae religiosae Perfectae caritatis (28.10.1965), AAS 58 (1966), pp. 702-712; tekst polski: Sobór Watykański II, Konstytucje. Dekrety. Deklaracje, s. 264-275.

${ }^{10}$ Concilium Oecumenicum Vaticanum II, Decretum de apostolatu laicorum Apostolicam actuositatem (18.11.1965), AAS 58 (1966), pp. 757-787; tekst polski: Sobór Watykański II, Konstytucje. Dekrety. Deklaracje, s. 377-401.

${ }^{11}$ Concilium Oecumenicum Vaticanum II, Decretum de activitate missionali ecclesiae Ad gentes (07.12.1965), AAS 58 (1966), pp. 950-951; tekst polski: Sobór Watykański II, Konstytucje. Dekrety. Deklaracje, s. 433-471.

12 Pontificia Commissio Codici Iuris CAnONici Recognoscendo, Relatio, complectens sinthesim animadversionum ab Em.mis atque Exc.mis Patribus commissionis ad novissimum schema Codicis Iuris Canonici exhibitarum, cum responsibus a secretatia et consultoribus datis, Typis Polyglotis Vaticanis 1981, s. 285-286.
} 
Prawa Kanonicznego nie wyraził własnej rekomendacji co do postawionego postulatu J. Bernardina ${ }^{13}$. Mimo braku odpowiedzi na postawiony postulat, to jednak wyrażenie, aby konferencja biskupów określiła akty nadzwyczajnego zarządzania, zostało włączone do schematu kanonów z 1982 r., a następnie, bez żadnych zmian przepis ten wszedł do obowiązującego KPK/83.

Przedstawiona geneza aktów nadzwyczajnego zarządzania ostatecznie nie daje odpowiedzi, dlaczego konferencja biskupów zobowiązana jest do ustanowienia aktów nadzwyczajnego zarządzania, a nie biskup diecezjalny (kan. $1281 \S 1-2)$.

\section{POJĘCIE AKTÓW NADZWYCZAJNEGO ZARZĄDZANIA}

Łacińskie pojęcie actus extraordinariae administrationis Ustawodawca tylko raz zastosował w kan. 1277 KPK/83. Przy czym dalej nie wyjaśnia tego terminu ani jego znaczenia. Znamienny jest również fakt, że dla osób prawnych podległych biskupowi diecezjalnemu Ustawodawca zastosował zgoła inny termin, a mianowicie „akty, które przekraczają granice i sposób zwyczajnego zarządzania" (kan. $1281 \S 2$ ). Podobne sformułowanie zastosowano w przepisach o zarządzaniu w instytutach zakonnych (kan. $638 \S 1)^{14}$. Paralelne sformułowanie zostało również zawarte w Kodeksie Kanonów Kościołów Wschodnich ${ }^{15}$ : „akty, które przekraczają granicę i sposób zwyczajnego zarządzania" (kan. 1024 KKKW).

Połączenie dwóch sformułowań zawartych w kan. 1277 i $1281 \S 1-2$ pozwala wyodrębnić dwa kryteria w określeniu, czym są akty nadzwyczajnego zarządzania, mianowicie to granice i sposób zwyczajnego zarządzania. Kryterium fines dotyczy granic, które przekraczają zwyczajne zarządzanie. Natomiast modum odnosi się do sposobu jego wykonania, czyli uzyskania zgody kolegialnych organów konsultacyjnych (kan. 1277) ${ }^{16}$.

13 J.A. RENKEN, Acts of extraordinary administration of ecclesiastical goods in book Vof the CIC, „Studia Canonica” 49 (2015), s. 585.

${ }^{14}$ Więcej na temat rozróżnienia tychże sformułowań zob. L. ŚwiTo, Akty zarządu dobrami kościelnymi, s. 105.

${ }^{15}$ Codex Canonum Ecclesiarum Orientalium auctoritate Ioannis Pauli PP. II promulgatus (18.10.1990), AAS 82 (1990), s. 1033-1363; Kodeks Kanonów Kościołów Wschodnich promulgowany przez Papieża Jana Pawła II, przekład polski L. Adamowicz, M. Dyjakowska, Lublin 2002 [dalej: KKKW].

${ }^{16}$ P. KALETA, Prawne aspekty zarzadzania dobrami, s. 34. 
W aspekcie ustanowienia aktów nadzwyczajnego zarządzania warto dodać, że dyspozycja prawna zawarta w kan. 1277 i 1281 § 2 wskazuje na dwa różne podmioty je określające, tj. na konferencję biskupów oraz na biskupa diecezjalnego. Ten ostatni ustala akty nadzwyczajnego zarządzania dla podległych mu osób prawnych dopiero wtedy, gdy statuty tychże osób ich nie precyzują (kan. 1281 § 2). W tym kontekście Francis Morrisey snuje refleksję, że w przyszłości niektóre konferencje biskupów będą mogły dokonać rewizji własnych ustaleń i być może skoncentrują się na dyspozycji prawnej zawartej w kan. $1281 \S 1$, aby biskup diecezjalny sam określił, które akty przekraczają granicę i sposób zwyczajnego zarządzania ${ }^{17}$.

\section{OKREŚLENIE AKTÓW NADZWYCZAJNEGO ZARZĄDZANIA}

Zgodnie z kan. 1277 konferencja biskupów ma określić, które akty należy uznać za akty nadzwyczajnego zarządzania. W polskim przekładzie KPK/83 łaciński czasownik definire błędnie przetłumaczono jako „zaliczyć”. W istocie chodzi tu o zdefiniowanie lub uściślenie, które akty administracji majątkiem kościelnym są aktami nadzwyczajnego zarządzania. Zoila Combalía w komentarzu do kan. 1277 słusznie dodaje, że określenie aktów nadzwyczajnego zarządzania przez konferencję biskupów ma na celu ujednolicenie kryteriów uznania tychże aktów w obrębie danego terytorium lub regionu, w którym działa konferencja ${ }^{18}$.

W komentarzach do obecnego KPK/83 wykładnia porównawcza analizowanego kanonu jest jednomyślna ${ }^{19}$. Konferencja biskupów określa akty nadzwyczajnego zarządzania dla diecezji (kan. 1277), natomiast biskup diecezjalny zgodnie z kan. $1281 \S 2$ - dla podległych mu osób prawnych (np. dla

${ }^{17}$ F.G. MORRISEY, Ordinary and Extraordinary Administration. Canon 1277, „The Jurist” 48 (1988), nr 2, s. 720.

${ }^{18}$ Z. Combalía, The Administration of Goods, [w:] Exegetical Commentary on the Code of Canon Law, red. Á. Marzoa, J. Miras, R. Rodríguez-Ocaña, t. IV/1, Montreal-Chicago: Wilson \& Lafleur 2004, s. 96.

${ }^{19}$ V. De Paolis, Los bienes temporales de la Iglesia, Madrid: Biblioteca de Autores Cristianos 2012, s. 175; por. M. LóPEZ AlarCón, The Temporal Goods of the Church, [w:] Code of Canon Law Annotated, red. E. Caparros, M. Thériault, J. Thorn, Montréal-Chicago: Wilson \& Lafleur 2004, s. 985; A. ZAMBON, I beni ecclesiastici. Amministrazione e vigilanza, „Quaderni di Diritto Ecclesiale” 28 (2015), s. 202-229; J.A. RenKen, Canon 1277 and 1281. Acts of Extraordinary Administration, [w:] Roman Replies \& CLSA Advisory Opinions 2010, red. S.A. Euart [i in.], Washington: R.R. Bowker 2010, s. 162. 
parafii). Konferencja biskupów nie ma tu żadnych kompetencji do określania tych aktów podmiotom niepodlegającym jej władzy. Dla instytutów zakonnych, na przykład, akty nadzwyczajnego zarządzania reguluje prawo własne instytutu (kan. $638 \S 1)$.

Trzeba jednak zaznaczyć, że cały kontekst kan. 1277 odnosi się do majątku diecezjalnego. Wspomniany kanon wyraźnie wskazuje na statu oeconomico diocesis, którego zarządcą jest biskup diecezjalny. Dokonanie aktu nadzwyczajnego zarządzania nie należy do ekonoma, lecz do biskupa diecezjalnego (zob. kan. $134 \S 3$ ), który może tego dokonać dopiero po uzyskaniu zgody (łac. consensus) diecezjalnej rady ds. ekonomicznych i kolegium konsultorów.

Zgodnie z kan. 455 § 2 konferencja biskupów powinna wydać dekret, który jest ważny, gdy został podjęty na sesji plenarnej, a opowie się za nim przynajmniej dwie trzecie głosów biskupów należących do konferencji biskupów z głosem decydującym. Ustanowiony dekret wchodzi w życie dopiero wtedy, gdy zostanie przejrzany (łac. recognitio) przez Stolicę Apostolską (zob. art. $82 \mathrm{~PB})^{20}$. Nie można zatem uznać za obowiązujące przepisy o aktach nadzwyczajnego zarządzania, które zostały ustanowione za pomocą instrukcji (kan. 34), jak np. dokonała tego Konferencja Biskupów Włoch ${ }^{21}$.

Jak już wspomniano we wstępie, Konferencja Episkopatu Polski nie określiła aktów nadzwyczajnego zarządzania dla diecezji, a w Instrukcji w sprawie zarządzania dobrami doczesnymi Kościoła z 2015 r. znalazła się zapowiedź, że: „Wykaz aktów nadzwyczajnego zarządzania zostanie ustalony przez Konferencję Episkopatu Polski w odrębnym akcie prawnym" (IKEP 3, 34). W sytuacji zaś braku określenia aktów nadzwyczajnego zarządzania pojawić się może pytanie, czy dla diecezji przewidziane są inne akty nadzwyczajnego zarządzania niż te, które ustanowić powinna konferencja biskupów? W odpowiedzi na tę wątpliwość należy wskazać na kan. 1277, według którego akty nadzwyczajnego zarządzania są nie tylko określane przez konferencję biskupów, lecz także wymienione zostały w prawie powszechnym (łac. in iure universali) oraz mogą zostać sformułowane w dokumentach fundacyjnych (łac. tabulis fundationis).

\footnotetext{
${ }^{20} \mathrm{Na}$ mocy art. 98 konstytucji apostolskiej Pastor bonus zatwierdzenia udziela Kongregacja ds. Duchowieństwa.

${ }^{21}$ La CONFERENZA EPISCOPAle ItAliana, Istruzione in materia amministrativa 2005, Milano 2006, s. 161-165.
} 
4.1. Akty nadzwyczajnego zarządzania w prawie powszechnym

Analiza przepisów prawnych KPK/83 pozwala wyszczególnić siedem kanonów wskazujących na akty nadzwyczajnego zarządzania, które odnoszą się do wszystkich publicznych osób prawnych w Kościele. Istotną ich charakterystyką jest uzyskanie zezwolenia ordynariusza (zob. kan. $1281 \S 1$ ) na dokonanie takiego aktu. Do nich należy m.in.:

1) Budowa nowego kościoła (kan. 1215).

2) Odmowa przyjęcia ofiary w sprawach większej wagi (kan. 1267 § 2).

3) Przyjęcie ofiar $\mathrm{z}$ obciążeniem określającym sposób korzystania lub stanowiącym warunek (kan. 1267 §).

4) Ulokowanie pieniędzy po pokryciu wydatków na korzyść osoby prawnej (kan. $1284 \S 2,6^{\circ}$ ).

5) Wszczęcie sprawy lub zawiązanie sporu w sądzie państwowym (kan. $1288)^{22}$.

6) Dzierżawa dóbr kościelnych małej wartości (kan. 1297) ${ }^{23}$.

7) Zabezpieczenie pieniędzy i dóbr ruchomych, które zostały przydzielone tytułem dotacji dla nieautonomicznej fundacji pobożnej (kan. 1305).

\subsection{Akty nadzwyczajnego zarządzania w dokumentach fundacyjnych}

Akty nadzwyczajnego zarządzania mogą zostać ustanowione przez fundatora. Darczyńca, przekazując własne dobra na cele kościelne, może ustanowić własne wymogi zarządzania darowanego majątku ${ }^{24}$. Ustawodawca jednak nie precyzuje granic jego kompetencji co do ustanowienia praw nad przekazanym majątkiem. Do dokumentów fundacyjnych odnosi się również kan. $1267 \S 2$, w którym zawarty jest wymóg uzyskania zezwolenia od ordynariusza na przyjęcie ofiar obwarowanych warunkiem lub sposobem z nich korzystania. Konferencja Episkopatu Polski w Instrukcji w sprawie zarzadzania dobrami doczesnymi Kościoła jako przykłady ofiar z obciążeniem podającym sposób korzystania wymienia: darowizny obciążone hipoteką, zastawem, służebnością oraz dzierżawę (IKEP 2, 9).

\footnotetext{
${ }^{22}$ Należy zauważyć, że pisemne zezwolenie, o którym mowa w kan. 1288, wymagane jest do sądu państwowego. Jednak tego typu zezwolenie nie jest wymagane w przypadku sądu kościelnego (por. kan. 1480). Domniemywa się, że w przypadku roszczeń małego znaczenia nie jest wymagane pisemne zezwolenie własnego ordynariusza.

${ }^{23} \mathrm{~W}$ przypadku dzierżawy dóbr o większej wartości należy zastosować kan. 1295, ponieważ istnieje ryzyko, że wydzierżawiany majątek może znaleźć się w gorszej sytuacji.

${ }^{24}$ Zob. A. DomAsZK, Dobra doczesne Kościoła, Warszawa: Wydawnictwo UKSW 2016, s. 206.
} 
W kontekście braku określenia aktów nadzwyczajnego zarządzania przez konferencję biskupów można rozpatrzyć inną możliwość, w szczególności gdy podejmowana czynność nie odpowiada żadnemu z wymienionych przykładów tych aktów ujętych w prawie powszechnym czy w dokumentach fundacyjnych, w takiej sytuacji biskup diecezjalny powinien rozważyć, czy podejmowana czynność należy do aktów o większym znaczeniu, czy jest to transakcja, która może pogorszyć stan majątkowy kościelnej osoby prawnej (kan. 1295). W pierwszym przypadku biskup powinien uwzględnić stan ekonomiczny diecezji, np. jego roczne obroty finansowe, jeśli dana czynność mieści się $\mathrm{w}$ rocznym preliminarzu budżetowym, to powinien dokonać aktu o większym znaczeniu. W drugim zaś przypadku, biskup powinien wziąć pod uwagę kryterium, czy dana transakcja może pogorszyć stan majątkowy kościelnej osoby prawnej. W literaturze przedmiotu podaje się następujące przykłady takich czynności: 1) zaciąganie pożyczki; 2) ustanowienie hipoteki lub służebności gruntowej; 3) zrzeczenie się służebności przysługującej kościelnej osobie prawnej; 4) kredyt pod zastaw rzeczy kosztownych; 5) udzielanie gwarancji dla pożyczek innych osób; 6) zawieranie długoterminowych umów o dzierżawę lub najem; 7) nabywanie lub sprzedaż dóbr kościelnych, których wartość nie przekracza wartości minimalnej dla alienacji; 8) zmiana w statusie własności, np. przekształcanie niektórych form własności w spółki; 9) podejmowanie inwestycji finansowanych z projektów unijnych ${ }^{25}$.

Trzeba również uwzględnić kolejną sytuację, gdy dana czynność prawna nie ma wpływu na stan ekonomiczny diecezji, wówczas należy tę czynność uznać za akt zwyczajnego zarządzania ${ }^{26}$.

\section{APLIKACJA KAN. 1277 PRZEZ WYBRANE KONFERENCJE BISKUPÓW}

Chociaż zasada wyrażona w kan. 1277 wydaje się jasna co do określenia przez konferencję biskupów, które akty należy uznać za akty nadzwyczajnego zarządzania, to jednak aplikacja tej dyspozycji prawnej w praktyce może być różna. Przeprowadzona analiza dekretów wybranych konferencji ${ }^{27}$ wskazuje,

${ }^{25}$ J.A. Renken, Threatening Contracts. The Discipline and Application of Canon 1295, „Studia Canonica” 45 (2011), s. 501-519.

${ }^{26}$ Por. P. Kaleta, Prawne aspekty zarzadzania dobrami, s. 79.

${ }^{27}$ Badanie nt. postanowień konferencji biskupów było już podejmowane m.in. przez S. DuBIEL, Uprawnienia majątkowe Kościoła Katolickiego w Polsce w świetle Kodeksu Prawa Kanonicznego z 1983 r., Konkordatu z 1993 r. i ustaw synodalnych, Lublin: Wydawnictwo KUL 2007, s. 54-55; 
że konferencja może przyjąć trzy kryteria w ustaleniu aktów nadzwyczajnego zarządzania: a) kryterium górnej granicy finansowej, b) kryterium rodzajowe, c) kryterium mieszane.

\subsection{Kryterium górnej granicy finansowej}

Przykładem przyjętej granicy finansowej jest dekret Konferencji Biskupów Australii z 4 października 1985 r., w którym uznano za akty nadzwyczajnego zarządzania te, za które diecezja będzie zobowiązana do rocznej spłaty kapitału i odsetek powyżej 50 centów na mieszkańca danej diecezji lub 100000 USD, w zależności od tego, która wartość okaże się wyższa ${ }^{28}$. Przy czym każda z tych kwot podlega waloryzacji, uwzględniając stopę inflacji dokonaną przez sekretariat konferencji biskupów. Aktualna stopa inflacji jest publikowana w pierwszym numerze danego roku w czasopiśmie „Canonist”.

Wskazanie na górną granicę finansową dla aktów nadzwyczajnego zarządzania wydaje się najbardziej czytelne dla biskupa. W ten sposób będzie on mógł wyraźnie odróżnić akty nadzwyczajnego zarządzania (kan. 1277) od transakcji, która może pogorszyć stan majątkowy kościelnej osoby prawnej (kan. 1295). Do podobnej konkluzji doszła Kongregacja ds. Instytutów Życia Konsekrowanego i Stowarzyszeń Życia Apostolskiego w wytycznych z dnia 12 grudnia 2017 r. Ekonomia w stużbie charyzmatu i misji, w których zaleciła, aby każda kapituła generalna określiła najwyższą sumę wydatków dla nadzwyczajnych aktów zarządzania $(\mathrm{nr} 58)^{30}$.

\subsection{Kryterium rodzajowe}

Drugim kryterium stosowanym w określeniu aktów nadzwyczajnego zarządzania jest rodzaj aktu. Jednym z takich przykładów jest dekret Konferencji

L. ŚwiTo, Akty zarządu dobrami kościelnymi, s. 107. W niniejszym badaniu zostaną zaprezentowane przykłady ustalonych kryteriów określenia aktów nadzwyczajnego zarządzania stosowanych przez konferencje biskupów.

${ }^{28}$ Australian CATHOLIC Bishops CONFERENCE, Complementary legislation for Australia pertaining to Acts of Extraordinary Administration and Alienation, https://www.catholic.org.au/acbcmedia/downloads/ad-limina/bishops-1/handbook-1/1400-alienation-and-extraordinary-administra tion-1/file [dostęp: 20.02.2021].

${ }^{29}$ J. Power, Corporate and Canonical Go ate and Canonical Governance: Understanding Church Property, „The University of Notre Dame Australia Law Review” 21 (2019), nr 2, s. 17.

${ }^{30}$ Kongregacja DS. Instytutów ŻyCia KonseKrowanego i STOWARZYSZEŃ ŻYCIA APOSTOLSKIEGO, Ekonomia w stużbie charyzmatu i misji. Ukierunkowania, Niepokalanów 2019, s. 82. 
Biskupów Stanów Zjednoczonych z dnia 13 listopada 2007 r. Za akty nadzwyczajnego zarządzania konferencja uznała:

1) Podejmowanie programu finansowania poprzez emisję instrumentów finansowych, jak: obligacje, roczne renty, zawieranie kredytów hipotecznych i pożyczek bankowych powyżej kwoty minimalnej określonej według kan. $1292 \S 1$.

2) Wydzielanie pojedynczego lub wszystkich roszczeń finansowych powyżej kwoty minimalnej ustalonej według kan. $1292 \S 1$.

3) Zaangażowanie się w regularny zarząd lub wykonywanie działalności handlowej, lub gospodarczej, która nie jest zasadniczo związana z działalnością religijną, duchową, edukacyjną lub charytatywną Kościoła, których celem jest generowanie dochodów na prowadzenie takiej działalności.

4) Zawarcie jakiejkolwiek transakcji finansowej lub umowy, której postanowienia dotyczą kwestii rzeczywistego udziału lub potencjalnego konfliktu interesów dla biskupa diecezjalnego, biskupa/ów pomocniczego/ych, wikariusza/y generalnego/ych, wikariusza/y biskupiego/ich lub ekonoma diecezjalnego ${ }^{31}$.

W celu lepszego zrozumienia przywołanych rodzajów aktu warto nadmienić, że dekret ten został poprawiony przez konferencję amerykańskich biskupów, ponieważ poprzedni dekret z dnia 27 października 1986 r. nie uzyskał recognitio od Kongregacji ds. Duchowieństwa. Okazało się, że do aktów nadzwyczajnego zarządzania zaliczono również te, które w istocie były aktami alienacji, jak sprzedaż dóbr kościelnych czy przeniesienie prawa własności na inny podmiot ${ }^{32}$. Podobną omyłkę popełniła Konferencja Biskupów Kanady i w $1991 \mathrm{r}$. wydała poprawiony dekret ${ }^{33}$.

\subsection{Kryterium mieszane}

Oprócz dwóch wyżej wymienionych kryteriów, należy dodać jeszcze trzeci przykład, który ma postać kryterium mieszanego. Polega ono na połączeniu dwóch poprzednich formuł, czyli kryterium finansowego z rodzajowym. Przykładem takiego rozwiązania jest dekret z dnia 18 stycznia 1986 r. Konferencji

\footnotetext{
${ }^{31}$ United States CONFERENCE of CATHOLIC Bishops, Canon 1277 - Acts of Extraordinary Administration by Diocesan Bishop, http://www.usccb.org/beliefs-and-teachings/what-we-believe/ canonlaw/complementary-norms/canon-1277-acts-of-extraordinary-administration-by-diocesan-bishop.cfm [dostęp: 12.02.2021]. Dekret ten uzyskał recognitio Kongregacji do spraw Biskupów na mocy art. 82 PB z dn. 19.12. 2009 (N. 778/2005).

${ }^{32}$ D.J. WalkowiaK, Ordinary and Extraordinary Administration, s. 189.

${ }^{33}$ Zob. NAtional CONFERENCE OF CATHOLic Bishops, Implementation of the 1983 Code of Canon Law. Complementary Norms, Washington 1991, s. 21.
} 
Biskupów Francji, w którym akty nadzwyczajnego zarządzania zostały podzielone na dwie kategorie: a) akty, które poważnie mogłyby wpłynąć na stan majątkowy diecezji; b) akty, które mogłyby wpłynąć na stabilność finansową $\mathrm{w}$ diecezji.

Do pierwszej kategorii należy: nabycie nieruchomości, których wartość jest wyższa o $25 \%$ rocznego przychodu, budowa lub przekształcenie budynków, gdy wydatki przekraczają $25 \%$ rocznych przychodów, zaciągnięcie kredytu lub oferowanie zastawu ponad $25 \%$ rocznego przychodu, kredyty dla osób prowadzących przedsiębiorstwa handlowe, gdy kwota przekracza 2,5\% rocznych dochodów.

Do drugiej kategorii należą: pożyczki, gdy ich wartość przekracza 5\% maksymalnej kwoty przewidzianej w kan. 1292 § 1, zawieranie umów z firmami, których działania są niezbędne lub przydatne dla Kościoła (np. księgarnie, wydawnictwa, stacje radiowe itp. $)^{34}$.

$\mathrm{Na}$ podstawie przeprowadzonej analizy wybranych dekretów konferencji biskupów można wyróżnić trzy rodzaje kryteriów dla określenia aktów nadzwyczajnego zarządzania: kryterium granicy finansowej, kryterium rodzajowe oraz kryterium mieszane. Ich elementem wspólnym jest cel dokonania aktu, który utożsamia się z definicją zarządzania ${ }^{35}$. Akty zarządzania, w tym również nadzwyczajnego mają na celu zachowanie majątku, podniesienie jego wydajności oraz przeznaczenie ich na cele kościelne. Należy tu podkreślić, że tego rodzaju akty są różne od alienacji czy transakcji, które mogą pogorszyć stan majątkowy kościelnej osoby prawnej. Z tego względu ustawodawca postanowił, że tego rodzaju akty będą usystematyzowane w odrębnych tytułach księgi V KPK/83.

\section{ZNACZENIE OKREŚLENIA}

\section{AKTÓW NADZWYCZAJNEGO ZARZĄDZANIA}

Zastosowanie w kan. 1277 łacińskiego czasownika habendi nie oznacza ,zalecenia”, lecz „powinność”, którą należy wykonać ${ }^{36}$. Sądzić należy, że taki stan

\footnotetext{
${ }^{34}$ Conference des ÉveQues de France, Promulgation de normes complémentaires, $d u$ droit canonique, Décret of January 28, 1986, „Bulletin” 30 (1986), s. 453-454; zob. P. KALETA, Kościelne prawo majątkowe, Lublin: Towarzystwo Naukowe KUL 2012, s. 204.

${ }^{35}$ Pontificio Consiglio Per i Testi Legislativi, Nota Esplicativa »La funzione dell'autorità ecclesiastica sui beni ecclesiastici«, „Communicationes” 36 (2004), s. 26.

${ }^{36}$ Zob. V. De PaOlis, Los bienes temporales de la Iglesia, s. 201.
} 
prawny wynika głównie $\mathrm{z}$ różnych aktów administracyjnych wyrażonych w księdze V KPK/83, które mogą być błędnie interpretowane. W szczególności, gdy chodzi o akty alienacji (kan. 1291), gdy kwota np. sprzedaży nie przekracza minimalnej wartości alienacji (kan. 1291), czy o jakąkolwiek transakcję, która może pogorszyć stan majątkowy kościelnej osoby prawnej (kan. 1295).

Akty nadzwyczajnego zarządzania, w odróżnieniu od jakiejkolwiek transakcji, o których mowa w kan. 1295, są określane przez konferencje biskupów. Poza tym akty nadzwyczajnego zarządzania odnoszą się do zarządzania dobrami, a nie do alienacji. Z pojęciowego punktu widzenia inny jest cel zarządzania (nawet nadzwyczajnego), a inny alienacji. Ustawodawca w kan. 1254 wyraźnie rozróżnia akty zarządzania od aktów alienacji, które Kościół ma prawo wykonywać na podstawie prawa wrodzonego (łac. ius nativum). Transakcje natomiast wyraźnie stoją w opozycji do zarządzania, obejmują one głównie umowy (kontrakty). O tym stanowi sam tytuł III księgi V KPK/83 De contractibus ac praesertim de alienatione. Federico Aznar Gil słusznie zauważył, że transakcje, które mogą pogorszyć stan majątkowy osoby prawnej, dotyczą dóbr określonych jako majątek stały (łac. patrimonium stabile). Termin ten został expressis verbis zastosowany w kan. 1295. Natomiast akty nadzwyczajnego zarządzania odnoszą się do pozostałych dóbr kościelnych innych niż patrimonium stabile ${ }^{37}$. Poza tym ustawodawca wobec transakcji nie podaje kryterium finansowego, ale wyraźnie wskazuje na kryterium, które może pogorszyć stan majątkowy kościelnej osoby prawnej.

Ich różnice pojawiają się również w procedurze wykonania. W celu dokonania aktu nadzwyczajnego zarządzania i niezależnie od tego, jaką kwotę obejmowałby ten akt, nie ma wymogu uzyskania zezwolenia od Stolicy Świętej ${ }^{38}$. Podobną konkluzję zawarła Konferencja Biskupów Włoch w Instrukcji w sprawie zarzadzania dobrami kościelnymi $(\mathrm{nr} 65)^{39}$. Nie każdy bowiem akt nadzwyczajnego zarządzania będzie transakcją, która pogorszy stan majątkowy osoby prawnej. Pożyczka bankowa bez zabezpieczenia hipotecznego nie będzie transakcją, która może pogorszyć stan majątkowy diecezji, ale aktem

${ }^{37}$ F.R. AZnAR GIL, Actos de administración ordinaria y extraordinaria. Normas canónicas, „Revista Española de Derecho Canónico” 2000, nr 57, s. 55; zob. P. KaletA, Prawne aspekty zarzadzania dobrami, s. 216.

${ }^{38}$ Por. P. Kaleta, Prawne aspekty zarzadzania dobrami, s. 215.

${ }^{39}$ LA CONFERENZA EPISCOPALE ITALIANA, Istruzione in materia amministrativa (2005), $\mathrm{nr}$ 65: Zezwolenie Stolicy Apostolskiej nie jest wymagane bez względu na wartość transakcji, chyba że jak wspomniano powyżej - transakcja podlega przepisom kan. 1295, biorąc pod uwagę konkretne elementy, które go charakteryzują. 
nadzwyczajnego zarządzania. Dlatego wydaje się konieczne, aby konferencja biskupów określiła, czym są a czym nie akty nadzwyczajnego zarządzania.

Velasio De Paolis twierdzi, że określenie aktów nadzwyczajnego zarządzania ma także istotne znaczenie dla organów kolegialnych, które zgodnie z kan. 1277 zobowiązane są udzielić zgody przed dokonaniem tegoż aktu ${ }^{40}$. Zarówno diecezjalna rada ds. ekonomicznych, jak i kolegium konsultorów powinny uzyskać niezbędne informacje, z jakim aktem administracyjnym mają do czynienia. Zgodnie z kan. 126 ignorancja lub błąd dotyczący samej istoty aktu powoduje, że akt został nieważnie podjęty, a w konsekwencji biskup diecezjalny nieważnie podejmuje akt nadzwyczajnego zarządzania (zob. kan. 127 § 1).

Biorąc pod uwagę sytuację prawną w Polsce, Konferencja Episkopatu Polski nie powinna zwlekać z określeniem aktów nadzwyczajnego zarządzania. Ustawy kanoniczne z samej natury wymagają ich przestrzegania ${ }^{41}$. Ich ustanowienie ułatwiłoby zarządcom w jasny sposób ich odróżnienie od innych aktów administracji i zwiększyłoby transparentnośćc ${ }^{42}$ finansów kościelnych w Polsce.

\section{PODSUMOWANIE}

Z przeprowadzonej analizy aktów nadzwyczajnego zarządzania należy wydobyć następujące wnioski.

Konferencja biskupów akty nadzwyczajnego zarządzania określa dla diecezji (kan. 1277), biskup diecezjalny dla podległych mu osób prawnych (kan. $1281 \S 2$ ), natomiast wyższy przełożony zakonny dla instytutu zakonnego (kan. $638 \S 1$ ).

Określenie aktów nadzwyczajnego zarządzania przez konferencję biskupów ma na celu ujednolicenie kryteriów uznania tychże aktów w obrębie danego terytorium oraz odróżnienie tychże aktów od jakiejkolwiek czynności, która może pogorszyć stan majątkowy kościelnej osoby prawnej (kan. 1295).

Konferencja biskupów w celu ustalenia aktów nadzwyczajnego zarządzania powinna wydać dekret (kan. $455 \S 2$ ), który powinien uzyskać recognitio od Stolicy Apostolskiej (art. 82 PB).

\footnotetext{
${ }^{40}$ Por. V. De Paolis, I beni temporali della Chiesa, Bologna: EDB Editore 2011, s. 208.

${ }^{41}$ Sanctus IoAnNes Paulus PP. II, Constitutio apostolica Sacrae discipline leges (25.01.1983), AAS 75 (1983), part I, p. VII-XIV.

${ }^{42}$ Zob. FrANCIS PP., Apostolic letter in the form of a Motu Proprio concerning certain competencies in economic and financial matters (28.12.2020), https://press.vatican.va/content/salastampa /en/bollettino/pubblico/2020/12/28/201228a.html [dostęp: 20.02.2021].
} 
Przeprowadzona analiza dekretów wybranych konferencji wskazuje trzy kryteria określania aktów nadzwyczajnego zarządzania: a) górnej granicy finansowej, b) rodzajowe oraz c) mieszane.

W sytuacji, gdyby akty nie zostały określone przez konferencję biskupów, wówczas biskup diecezjalny powinien sprawdzić, czy dokonywana czynność została sprecyzowana $\mathrm{w}$ prawie powszechnym i w dokumentach fundacyjnych. Jeśli zaś nie, powinien on rozważyć, czy podejmowana czynność należy do aktów o większym znaczeniu (kan. 1277) czy do transakcji, o której mowa w kan. 1295. Trzeba również uwzględnić kolejną sytuację, mianowicie gdy dana czynność prawna nie ma wpływu na stan ekonomiczny diecezji, to biskup podejmuje akt zwyczajnego zarządzania.

\section{BIBLIOGRAFIA}

\section{ŹRÓDŁA PRAWA}

Codex Canonum Ecclesiarum Orientalium auctoritate Ioannis Pauli PP. II promulgatus (18.10. 1990), AAS 82 (1990), s. 1033-1363; Kodeks Kanonów Kościołów Wschodnich promulgowany przez Papieża Jana Pawła II, przekład polski L. Adamowicz, M. Dyjakowska, Lublin: Wydawnictwo KUL 2002.

Codex Iuris Canonici auctoritate Ioannis Pauli PP. II promulgatus (25.01.1983), AAS 75 (1983), part II, s. 1-317; Kodeks Prawa Kanonicznego, przekład polski zatwierdzony przez Konferencję Episkopatu, Poznań: Pallottinum 1984.

Codex Iuris Canonici auctoritate Pii X Pontificis Maximi iussu digestus. Benedicti Papae XV auctoritate promulgatus (27.05.1917), AAS 9 (1917), part II, s. 2-523.

CONCILIUM OECUMENICUM VATICANUM II: Decretum de accommodata renovatione vitae religiosae Perfectae caritatis (28.10.1965), AAS 58 (1966), pp. 702-712; tekst polski: Sobór Watykański II, Konstytucje. Dekrety. Deklaracje, Poznań: Pallottinum 2002, s. 264-275.

Concilium Oecumenicum Vaticanum II: Decretum de activitate missionali ecclesiae $A d$ gentes (07.12.1965), AAS 58 (1966), pp. 950-951; tekst polski: Sobór Watykański II, Konstytucje. Dekrety. Deklaracje, Poznań: Pallottinum 2002, s. 433-471.

Concilium Oecumenicum Vaticanum II: Decretum de apostolatu laicorum Apostolicam actuositatem (18.11.1965), AAS 58 (1966), pp. 757-787; tekst polski: Sobór Watykański II, Konstytucje. Dekrety. Deklaracje, Poznań: Pallottinum 2002, s. 377-401.

Concilium Oecumenicum Vaticanum II: Decretum de presbyterorum ministerio et vita Presbyterorum ordinis (07.12.1965), AAS 58 (1966), pp. 991-1024; tekst polski: Sobór Watykański II, Konstytucje. Dekrety. Deklaracje, Poznań 2002, s. 478-508.

Conference des Éveques De France: Promulgation de normes complémentaires, du droit canonique, Décret of January 28, 1986, „Bulletin” 30 (1986), s. 453-454.

KONFERENCJA EPISKOPATU POLSKI: Instrukcja Konferencji Episkopatu Polski w sprawie zarządzania dobrami doczesnymi Kościoła (25.08.2015), „Akta Konferencji Episkopatu Polski” 27 (2015), s. $116-140$. 
KONGREGACJA DS. INSTYTUTÓW ŻYCIA KonSEKROWANEGO I STOWARZYSZEŃ ŻYCIA APOSTOLSKIEGO: Ekonomia w służbie charyzmatu i misji. Ukierunkowania, Niepokalanów 2019.

La CONFERENZA Episcopale ItAlianA: Istruzione in materia amministrativa 2005, Milano 2006, s. $161-165$.

National Conference of Catholic Bishops: Implementation of the 1983 Code of Canon Law. Complementary Norms, Washington 1991.

Pontificia Commissio Codici IURIS CANONICI ReCognoscendo: Relatio, complectens sinthesim animadversionum ab Em.mis atque Exc.mis Patribus commissionis ad novissimum schema Codicis Iuris Canonici exhibitarum, cum responsibus a secretatia et consultoribus datis, Vatican, Typis Polyglotis Vaticanis 1981, s. 285-286.

PONTIFICIO CONSIGLIO PER I TESTI LegiSLATIVI: Nota Esplicativa $»$ La funzione dell'autorità ecclesiastica sui beni ecclesiastici«, „Communicationes” 36 (2004), s. 24-32.

Sacra Congregatio de Propaganda Fide: Statuta generalia deconciliis quae bonis temporalibus ecclesiarum administrandis in archidioecesi Ultraiectensi et suffraganieis diocesibus proponuntur (21.07.1856), [w:] Codicis Iuris Canonici Fontes, red. Pietro Gasparri, Jusztinián Serédi, vol. VII, Typis Polyglottis Vaticanis 1926-1939, nr 4841, s. 347-348.

SAnCtus IoAnNes PAulus PP. II: Constitutio apostolica de Romana Curia Pastor Bonus (28.06.1988), AAS 80 (1988), s. 841-912; tekst polski w: Kodeks Prawa Kanonicznego. Komentarz, red. Piotr Majer, Kraków 2011, s. 1397-1465.

SAnctus IOANNES Paulus PP. II: Constitutio apostolica Sacrae discipline leges (25.01.1983), AAS 75 (1983), part I, p. VII-XIV.

\section{LITERATURA}

AZNAR GIL Federico R.: Actos de administración ordinaria y extraordinaria. Normas canónicas, „Revista Española de Derecho Canónico” 2000, nr 57, s. 41-70.

Combalía Zoila: The Administration of Goods, [w:] Exegetical Commentary on the Code of Canon Law, red. Ángel Marzoa, Jorge Miras, Rafael Rodríguez-Ocaña, t. IV/1, Montreal-Chicago: Wilson \& Lafleur 2004, s. 81-123.

DE PAOLIS Velasio: I beni temporali della Chiesa, Bologna: EDB Editore 2011.

DE PAOLIS Velasio: Los bienes temporales de la Iglesia, Madrid: Biblioteca de Autores Cristianos 2012.

DomASzK Arkadiusz: Dobra doczesne Kościoła, Warszawa: Wydawnictwo UKSW 2016.

Dubiel Stanisław: Akty nadzwyczajnego zarządzania w Kodeksie Prawa Kanonicznego z 1983 r., „Roczniki Nauk Prawnych” 25 (2015), nr 4, s. 113-131.

DubIEL Stanisław: Uprawnienia majątkowe Kościoła Katolickiego w Polsce w świetle Kodeksu Prawa Kanonicznego z 1983 r., Konkordatu z 1993 r. i ustaw synodalnych, Lublin: Wydawnictwo KUL 2007.

KALETA Paweł: Kościelne prawo majątkowe, Lublin: Towarzystwo Naukowe KUL 2012.

KALETA Paweł: Prawne aspekty zarządzania dobrami kościelnymi, Lublin: Wydawnictwo KUL 2017.

LÓPEZ Alarcón Mariano: The Temporal Goods of the Church, [w:] Code of Canon Law Annotated, red. Ernest Caparros, Michel Thériault, Jean Thorn, Montreal-Chicago: Wilson \& Lafleur 2004, s. 963-1016.

MORRISEY Francis G.: Ordinary and Extraordinary Administration. Canon 1277, „The Jurist” 48 (1988), nr 2, s. 709-726. 
Power Jeane: Corporate and Canonical Go ate and Canonical Governance:Understanding Church Property, "The University of Notre Dame Australia Law Review" 21 (2019), nr 2, s. 1-25.

RENKEN John A.: Acts of extraordinary administration of ecclesiastical goods in book V of the CIC, „Studia Canonica” 49 (2015), s. 577-596.

RENKEN John A.: Canon 1277 and 1281. Acts of Extraordinary Administration, [w:] Roman Replies \& CLSA Advisory Opinions 2010, red. Sharon A. Euart [i in.], Washington: R.R Bowker 2010, s. $162-168$.

RenKen John A.: Threatening Contracts. The Discipline and Application of Canon 1295, „Studia Canonica" 45 (2011), s. 501-519.

Świto Lucjan: Akty zarządu dobrami kościelnymi, „Prawo Kanoniczne” 58 (2015), nr 3, s. 105-116.

WALKOWIAK David J.: Ordinary and Extraordinary Administration, [w:] Church Finance Handbook, red. Kevin E. McKenna, Lawrence A. DiNardo, Joseph W. Pokusa, Washington: Canon Law Society of America 1999, s. 185-206.

ZAMBON Adolfo: I beni ecclesiastici. Amministrazione e vigilanza, „Quaderni di Diritto Ecclesiale” 28 (2015), s. 202-229.

\section{NETOGRAFIA}

Australian CATHOlic Bishops ConfERENCE: Complementary legislation for Australia pertaining to Acts of Extraordinary Administration and Alienation, https://www.catholic.org.au/acbc-media/down loads/ad-limina/bishops-1/handbook-1/1400-alienation-and-extraordinary-administration-1/file [dostęp: 20.02.2021].

FRANCIS PP.: Apostolic letter in the form of a Motu Proprio concerning certain competencies in economic and financial matters (28.12.2020), https://press.vatican.va/content/salastampa/en/ bollettino/pubblico/2020/12/28/201228a.html [dostęp: 20.02.2021].

LA CONFERENZA EPISCOPALE ITALIANA: Istruzione in materia amministrativa (2005), nr 65, https://www. chiesacattolica.it/documenti-segreteria/istruzione-in-materia-amministrativa-2005 [dostęp: 14.02. 2021].

United STATES CONFERENCE OF CATHOLIC Bishops: Canon 1277 - Acts of Extraordinary Administration by Diocesan Bishop, http://www.usccb.org/beliefs-and-teachings/what-we-believe/canon-law/ complementary-norms/canon-1277-acts-of-extraordinary-administration-by-diocesan-bishop.cfm [dostęp: 12.02.2021]. Dekret uzyskał recognitio Kongregacji do spraw Biskupów na mocy art. 82 PB z dn. 19.12.2009 (N. 778/2005).

\section{UPRAWNIENIE KONFERENCJI BISKUPÓW DO USTANOWIENIA AKTÓW NADZWYCZAJNEGO ZARZĄDZANIA}

$$
\text { Streszczenie }
$$

Celem artykułu jest ukazanie wymogu prawnego ustanowienia aktów nadzwyczajnego zarządzania przez konferencję biskupów (kan. 1277 in fine). W Polsce, jak dotąd, Konferencja Episkopatu ich nie zdefiniowała. Analiza prawa partykularnego innych konferencji wskazuje na ukształtowanie się trzech kryteriów, za pomocą których są określane akty nadzwyczajnego zarządzania. Wymóg prawa kanonicznego stanowi, że akty te nie mogą być określane na podstawie instrukcji, lecz dekretu 
(kan. 455). Aby mógł on wejść w życie, powinien uzyskać recognitio od Kongregacji ds. Duchowieństwa. Ustalenie, które akty należy uznać za akty nadzwyczajnego zarządzania, jest kluczowe dla rozróżnienia tychże aktów od transakcji, która może pogorszyć stan majątkowy kościelnej osoby prawnej (kan. 1295), oraz istotne dla organów kolegialnych udzielających zgody na dokonanie tychże aktów (kan. 1277).

Słowa kluczowe: akty nadzwyczajnego zarządzania; konferencja biskupów; transakcje, które mogą pogorszyć stan majątkowy osoby prawnej

\section{THE COMPETENCE OF THE CONFERENCE OF BISHOPS TO DEFINE ACTS OF EXTRAORDINARY ADMINISTRATION}

\section{S u m m a r y}

The article explores the legal requirement for defining the acts of extraordinary administration by the conference of bishops (can. 1277 in fine). In Poland, the Episcopal Conference has not yet defined these acts of administration. The analysis of the particular law of other conferences lays down three criteria for establishing acts of extraordinary administration. The requirement of canon law stipulates that those acts cannot be determined on the basis of the instructions, but the decree (can. 455). For the decree to enter into force it is to obtain recognition from the Congregation for the Clergy. Therefore, the above-mentioned acts are important not only to distinguish these acts from transactions which can worsen the patrimonial condition of a juridical person (can. 1295), but also for collective bodies who are to give the consent to place these acts (can. 1277).

Keywords: acts of extraordinary administration; bishops' conference; transaction, which can worsen the patrimonial condition of a juridical person 